\title{
2 LEONARDO DA VINCI, ARQUITECT? A PROPOSAL OF INTERVENTION IN THE DUOMO OF MILAN.
}

David Hidalgo ${ }^{1}$, Juan Manuel Santiago ${ }^{2}$ and Julián Arco ${ }^{3, *}$

1 Affiliation 1; PhD Higher Technical School of Building Engineering. Department of Architectural and Engineering Graphic Expression. University of Granada. Spain. dhidalgo@ugr.es.

2 Affiliation 2; PhD Higher Technical School of Building Engineering. Department of Architectural and Engineering Graphic Expression. University of Granada. Spain. santi@ugr.es

3 Affiliation 3; University Professor Higher Technical School of Building Engineering. Department of Architectural and Engineering Graphic Expression. University of Granada. Spain.juliannn@ugr.es

* Correspondence: dhidalgo@ugr.es; Tel.: +34-607-504-874

\begin{abstract}
Leonardo da Vinci (1452-1519) is considered one of the greatest geniuses of the Renaissance. His studies developed advanced ideas for his time, even in its most unknown aspects, such as: architecture, urban planning and restoration. He never studied formally, but he learned everything due to his method of observation, the study of other treatises and especially the group of artists with whom he collaborated. After the study of its codices a great interest and knowledge is detected, related to the design, the structural calculation, the materials and the constructive systems, in such a way that their proposals influenced the architecture of the Renaissance, through the work of other authors of your time. The purpose of this article is to make a critical analysis of its excellent architectural proposal in the cupola of the Duomo of Milan and the reasons why it was not carried out under its name. This proposal is included within a discipline in which it has never been recognized as such, but which demonstrated the same qualities as in other fields where it is recognized prestigiously.
\end{abstract}

Keywords: Renaissance; architecture; Duomo; Leonardo; Bramante.

\section{Introduction}

Leonardo brilliantly shone as a painter, inventor, anatomist, sculptor, philosopher and writer; and proof of this are his excellent works of art, studies, projects and inventions. Its production can be visited in the main cities where it resided and its works of art are in the facilities of the best museums of the world. But so are his Codices, thanks to which we have been able to know and appreciate his knowledge and his passion for research. Its content has anticipated many advances in modern science, especially in the areas of anatomy, optics and hydraulics.

But not all areas of this artist have followed the same trajectory of exceptionality. That the cases of the branches related to architecture and urbanism, whose monitoring has been less, are compared, for example, with painting. This fact may be motivated by the fact that the number of studies conducted by Leonardo in these areas is lower than in other fields. For example, at present Leonardo does not know architectural or urban works, however there are thirty-four paintings painted by him. It is evident that the bibliographic repercussion of the indicated areas is insignificant compared to the existing ones of their paintings or inventions. But this circumstance does not imply that their architectural and / or urban studies are considered of lower quality or grandeur. 
In the middle of the sixteenth century, Giorgio Vasari, biographer, architect and painter, expressed in his book Vite de' più eccellenti architetti, pittori, escultori italiani, da Cimabue insino a' tempi nostri in relation to life and work Leonardo da Vinci:

And he not only exercised a profession, but all those in which the drawing intervened, had such a divine and marvelous intelligence and was a good geometer who not only practiced sculpture and architecture but wanted his profession to paint (Vasari, 2005).

Leonardo used learning and the method of observation (Chavez, 2003) for his studies, since he considered that everything was in nature and therefore, to acquire knowledge, it was only necessary to observe it. The author Tafuri related to the way of working that Leonardo followed in the architecture, said: "L'ostinatorigore leonardesco è l'unico strumento che permette di individuare le vie corrette della ricerca sperimental en elle discipline architettoniche" (Tafuri, 1972, note 25) (Appendix A-1). This method is also implicit in his exceptional architectural studies, especially the dome of the Milan Duomo (see figure 1).

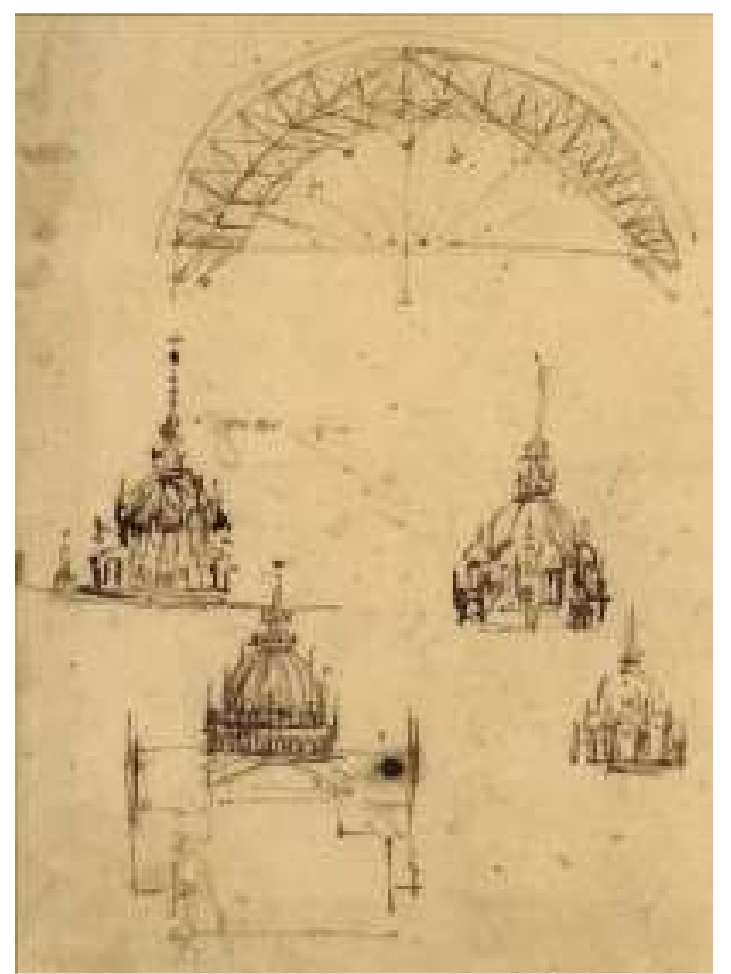

Figure 1: Studies for the base of Milan's Duomo. Atlantic Codex, page 719r. Source: Ambrosian's Library of Vinci.

Leonardo da Vinci can be considered among the group of autodidacts architects who acquired their knowledge through masters and the consultation of treaties. Thus, his stay in the workshop of Andrea de Verrochio in the city of Florence, or his joint works with Francesco di Giorgio (Appendix A-2), Donatelo Bramante (Appendix A-3) or Luca Pacioli (Appendix A-4) can be considered teacher-apprentice relations.

Leonardo acquisì gran parte delle sue conoscenze architettonich e attraverso un attento studio del Trattato di architettura militare e civile di Francesco di Giorgio Martini (Taglialagamba, 2010: 7) (Appendix A-5).

Leonardo's interest in architectural and urban problems and solutions is clearly shown in his Codices, especially in Manuscript B (Appendix A-6), corresponding to the period of 1483-1489 when 

he was in Milan under the command of Ludovico Sforza. Inside it can be found a kind of guide for architects that describe the organization of a complete city called città idéale.

\section{Results}

Leonardo's studies in architecture are very broad and varied, from topics related to new projects, restoration of buildings, repair of damages, problems of static and studies of elements and constructive systems. In the field of building, studies and proposals for action are assimilated to the three areas common in Renaissance architecture: religious buildings, civil buildings and military architecture.

Leonardo created many of the formal features of cinquecento architecture without having built a single building [. . . ] This was achieved in large part thanks to the influence he exerted on Bramante [... ] (Rowe, 2013: 32-33).

First major research carried out by Leonardo and related to architecture is in the project of the dome of Milan in 1487. At this time, Leonardo was already living in the city. A letter from Fancelli to Lorenzo de 'Medici of August 1487 confirms the architectural scope of the work: "La principal chagione è che la gupola qui par cheruinava, dondes' edisfata e vas investigando di rifarla" (Pedretti, 1988: 137) (Appendix A-7). His proposal for intervention is reflected profusely in the following Codex:

Table 1. Studies Duomo of Milan in Codices and Manuscripts of Leonardo da Vinci (Appendix A-8).

\begin{tabular}{ccc}
\hline Códex & Number pag. & Date \\
\hline ATLÁNTIC & $148 \mathrm{R}, 266 \mathrm{R}, 270 \mathrm{R}-\mathrm{C}, 310 \mathrm{R}-\mathrm{B}, 310 \mathrm{~V}-\mathrm{B}$, & 1487 \\
FOSTER & $850 \mathrm{R}, 850 \mathrm{~V}, 851 \mathrm{R}$ Y 851V. & \\
MANUSCRIT B & $54 \mathrm{~V}$ Y 55V & 1487 \\
TRIVULZIANO & $10 \mathrm{~V}$ Y 57 R & 1487 \\
& 3V-4R, 2V-3R, 8R-V, 9R, 11R, 21R, 22V & 1488 \\
& Y 27V & \\
\hline
\end{tabular}

In Figure 2, Leonardo represented eight possible ways to cover a square space. If these drawings are carefully observed, the one depicted in the lower right hand side closely resembles di Giorgio's definitive proposal subsequently approved by the Venerable Factory of the Duomo.

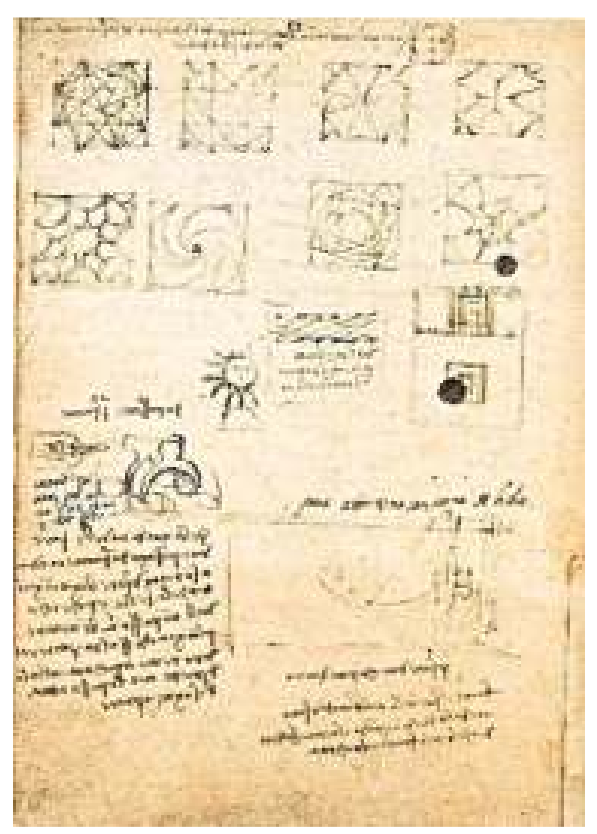

Figure 2: Proposals for roofs of the Dome base. Manuscript B, page 10v. From: Ambrosian Library of Vinci. 
102

103

104

105

106

107

108

109

110

111

112

Figure 3 shows some of the pages where Leonardo studied the configuration of the arches and the discharge walls of his proposal. But these representations could be considered as architectural studies and would not justify Leonardo's participation in the contest convened by the Venerable Factory between the years 1487-1490. In addition, it is striking that these studies of great architectural complexity, were realized simply by means of a system of two-dimensional representation of plant and elevation. Leonardo did not use his famous perspective in bird's eye view (Lotz, 1985: 30) (Appendix A-9), which would have made it easier to understand his studies. What might be the reason why Leonardo used (for one of the greatest projects of the entire Renaissance) a simpler representation system, based on plants and elevations?
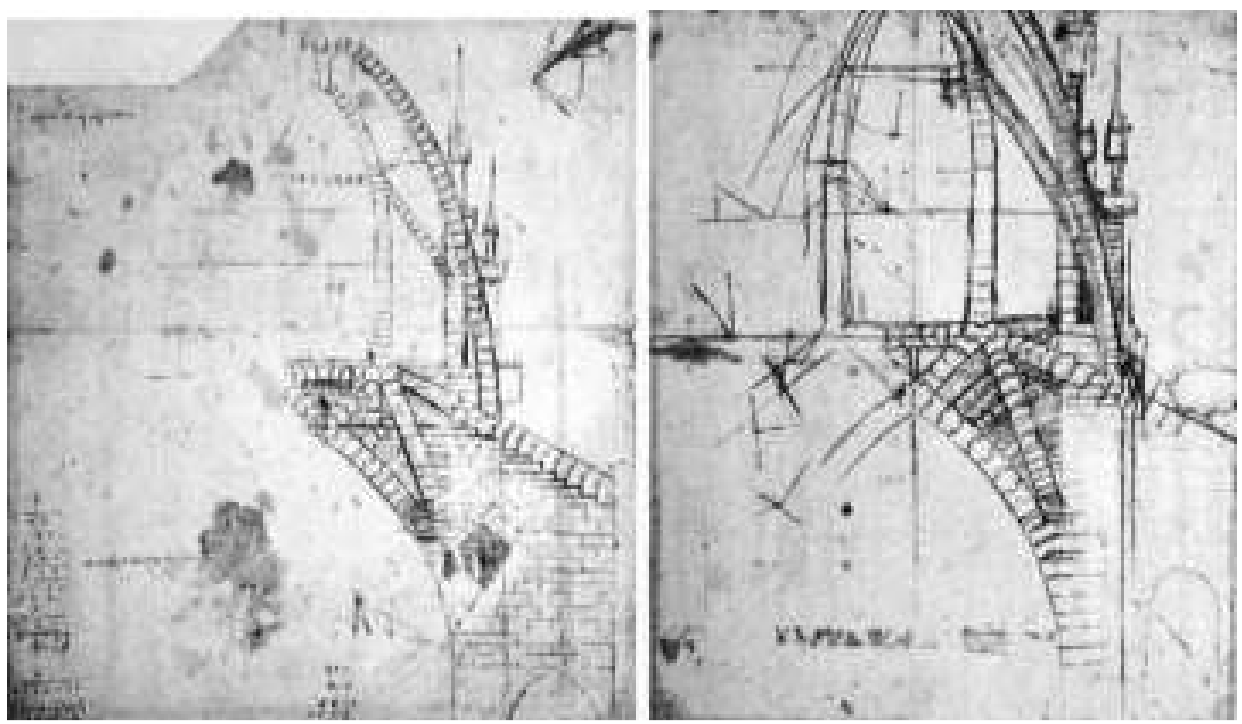

Figure 3: Studies about Archs of Milan's Duomo. Atlantic Codex, pag. 850r y 851v. From: Ambrosian's Library of Vinci.

The answer to this question is related to the first news that exists of his participation in the project. Leonardo forwarded to the carpenter Bernardino of Abbiate an amount of money for the accomplishment of a wooden model that contained his proposal of intervention (Pedretti, 1988). That is, given the magnitude of the architectural intervention to which it was presented, decided to develop a model. This technique (Appendix A-10) may seem original, but it is still a habitual work among the architects of the Renaissance and began in the fourteenth century (Taglialagamba, 2010).

But returning to the indications of Leonardo related to the arches of the project of Milan's Dome

The arc that quadruples the thickness will support four times the weight that could support the unitary arc, and more how less times the diameter if its thickness in its length. That is, if the thickness of the unitary arc fits ten times in its length, the thickness of the double arch will fit five times in its length. Consequently, since the thickness of the double arc only fits half a time in its length with respect to the unitary arc, it can be expected that it will be able to support half the weight of what it would bear if it were a ratio directly proportional to the unitary arc. Hence, since this double bow has four times the thickness of the unitary bow, it would seem that it should support four times the weight, but according to the rule described, it is clear that it can bear exactly eight times that weight. [...]. The way to give stability to the arc is to fill the sutures with good masonry up to the level of its keystone (Anna, 2006: 199).

Figure 4 shows his contributions to the study of arcs. The first image shows an arc that supports a load distributed symmetrically with respect to the vertical axis. In the second image an arc of double thickness is represented that the first one, therefore, should support four times more load than the first one. In the third image an arc is observed whose main characteristic is that its length contains ten times the thickness of the arc. It could support a specific load, represented by an arrow and on the axis of 
140

141

142

143

144

145

146

147

148

149

150

151

symmetry. In the last image it is observed how the length of the double arc only contains five times its thickness and therefore, can end up to support eight times more load than the one that contains ten times its thickness.
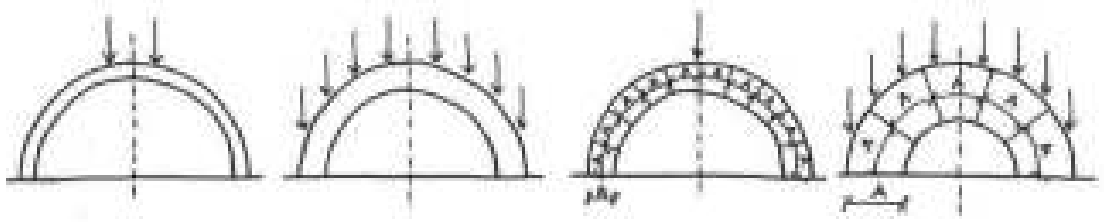

Figure 4: Arcs studies based on Leonardo (Author's photo).

On page $8 \mathrm{r}$ of the Trivulzian Codex (see Figure 5 (a)), it can be observed the elevation and several perspectives of the system proposed by Leonardo which consisted of an octagonal planar solution on which supports a double-layer dome which model was the one of Santa Maria del Fiore in Florence.

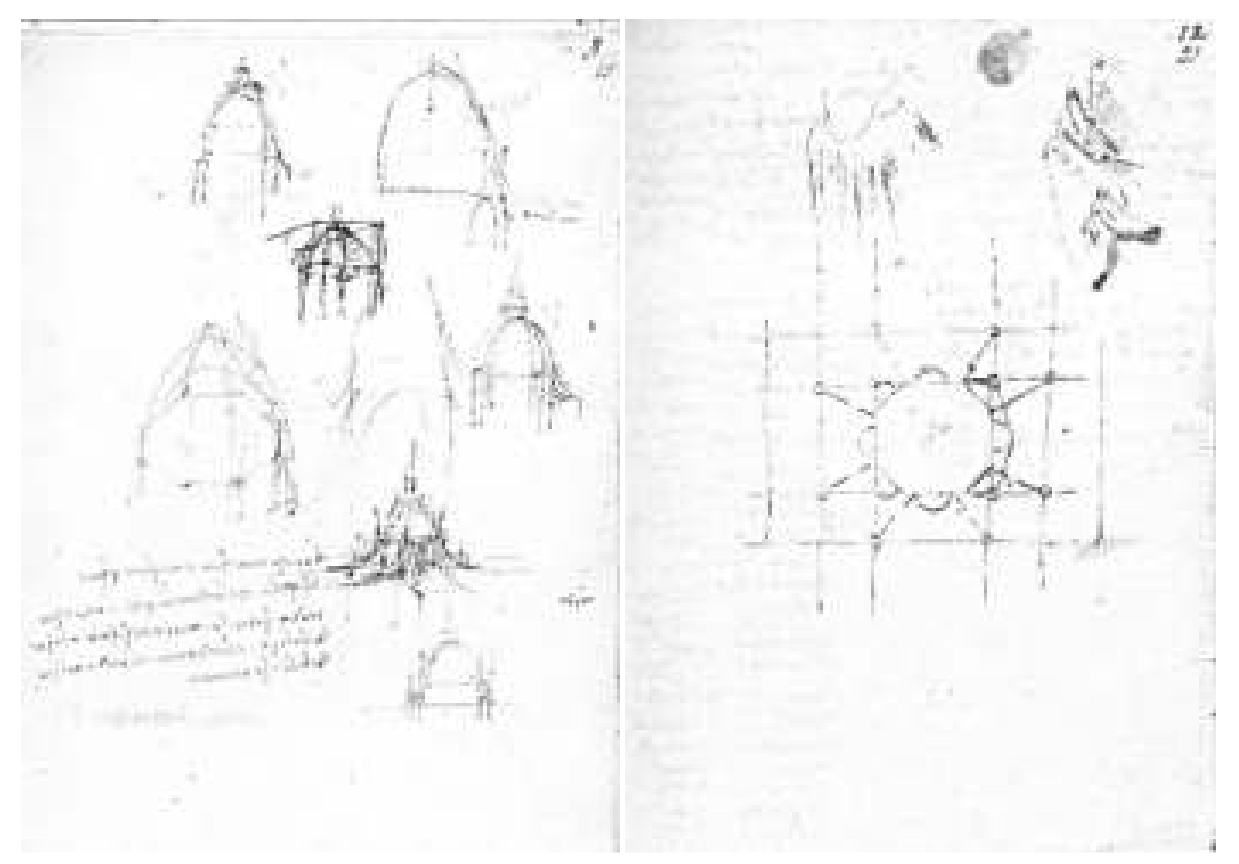

Figure 5: Studies of arcs of Milan's Dome. (a) Trivulzian Codex, pag. 8r y (b) Trivulzian Codex, pag 11r. From: Ambrosian's Library of Vinci.

On page 11r, (see figure $5(\mathrm{~b})$ ), and as a complement to the previous page, the floor of the system for the support of the dome is shown. In the assembly made on the basis of this page (see figure 6), it can be seen how the proposed system consists of the execution of four independent pillars of the structure of the Duomo and caged together by means of chains.

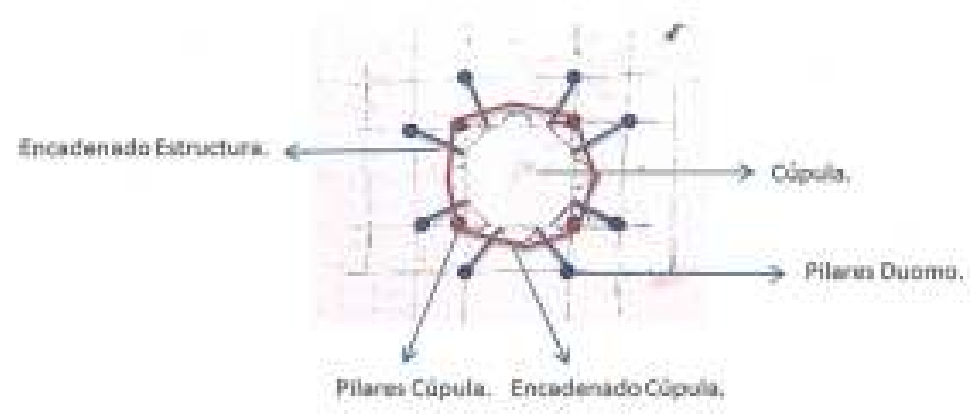

Figure 6: Proposed Scheme for Dome's base. From: Authors from page 11r, Trivulzian Codex. 
162

163

164

165

166

167

168

169

170

171

172

173

174

175

176

177

178

In this way, the weight would be distributed between the pillars, avoiding possible displacements and therefore, the appearance of cracks in the dome. In turn, and to obtain greater stability between the two elements, Leonardo proposes (see Figure 7), the anchorage by means of chains between the structure of the dome and that of the rest of the Duomo

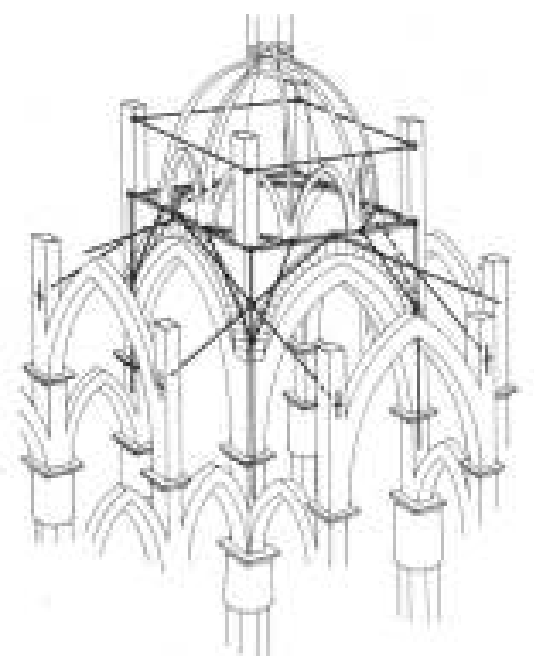

Figure 7: Reconstruction proposed by Francesco di Giorgio for the Milan's Duomo. From: Pedretti, Carlo, 1988,

Leonardo architetto. Electa Editions, Milan, pp. 36.

Therefore, it can be confirmed that Leonardo presented himself to the contest of the Dome of Milan, proposed by the venerable Factory between the years 1487-1490. However, there is further evidence of their participation in this project. It is proved that it was compensated with a total of 56 imperial lire in three installments: the first on August 9, 1487, the second on September 30, 1487 and the third on January 11, 1488, and all these payments (Pedretti, 1988) where made as a payment of "Riparazioni al modelo" (Appendix A-11). That is to say, it was not present only in the first phase of the contest but maintained its participation until the end. At the beginning of 1488, the model was completely finished, and this is confirmed by Leonardo himself in a letter reflected in the Atlantic Codex page 270r-c (see Figure 8), where he explains in detail the procedure adopted.

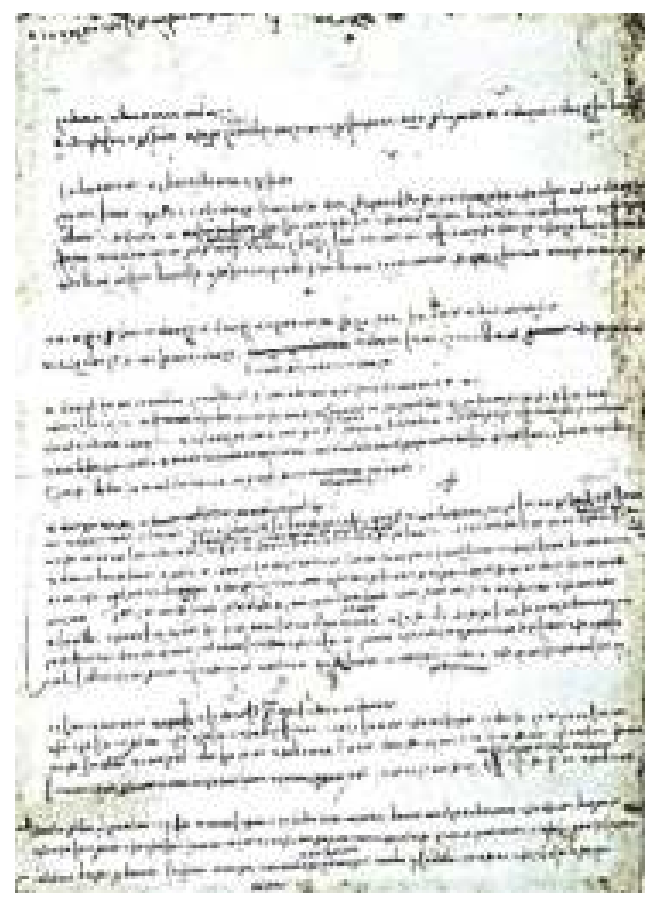

Figure 8: Letter from Leonardo to the Venerable Factory of the Duomo of Milan, Atlantic Codex, 270r-c. From:

Ambrosian Library of Vinci. 
182

183

184

185

186

187

188

189

190

191

192

193

194

195

196

197

198

199

200

201

202

203

204

205

206

207

208

209

210

211

212

213

Leonardo, through a safe study procedure planned loads and using a series of constructive elements made a proposal for intervention for the dome. This process is the one established by the famous architect of the Renaissance Leon Battista Alberti in the definition he made as an architect:

\begin{abstract}
Architect will be one who with a method and procedure determined and worthy of admiration has studied how to project in theory and also to carry To practice any work that, from the displacement of weights and union and the assembly of the bodies, is adapted, in a most beautiful way, to the most appropriate needs of human beings (Battista, 1991: 57).
\end{abstract}

The proposal indicated is very similar to the one that Bramante (Battista, 1991) did in the year 1506 for the Basilica of San Pedro. This would confirm several elements: on the one hand the friendship between the two, since Bramante adopted the proposal of Leonardo for a later work and the second and more important is that when adopting Bramante the proposal of Leonardo would demonstrate the architectural validity of the studies of Leonardo.

Francesco di Giorgio arrived in Milan at the end of May 1490 with the intention of preparing his proposal of intervention in the city's Duomo. On June 8, 1490, Ludovico Sforza claimed Francesco di Giorgio, Leonardo and Amadeo (Bruschi, 1987) for a consultation on the works of the Cathedral of the town of Pavia (Appendix A-12). On June 27 there was a meeting between the members of the factory and the contestants to proceed to establish the final decision. In this final award procedure, Leonardo's proposal was not named (Pedretti, 1988) and where confirmed Francesco di Giorgio, Amadeo and Dolcebuono as architects of the dome (Appendix A-13). Francesco had arrived to Milan not more than a month, in addition had had to make a trip with Leonardo to Pavia (Taglialagamba, 2010).

Everything indicated suggests that the model of Leonardo could be used by Francesco di Giorgio for his final proposal. An action carried out by Leonardo who would advance his friendship with Francesco and allow him to expand the knowledge of architecture of the young and inexperienced Leonardo. The final and approved proposal is very similar to Leonardo's, although it differs somewhat from Leonardo, since the approved one establishes a master arc that does not appear in Leonardo's documents (see Figure 9). However, in the figure indicated the dome pillars and the anchors are indicated by chains previously indicated.

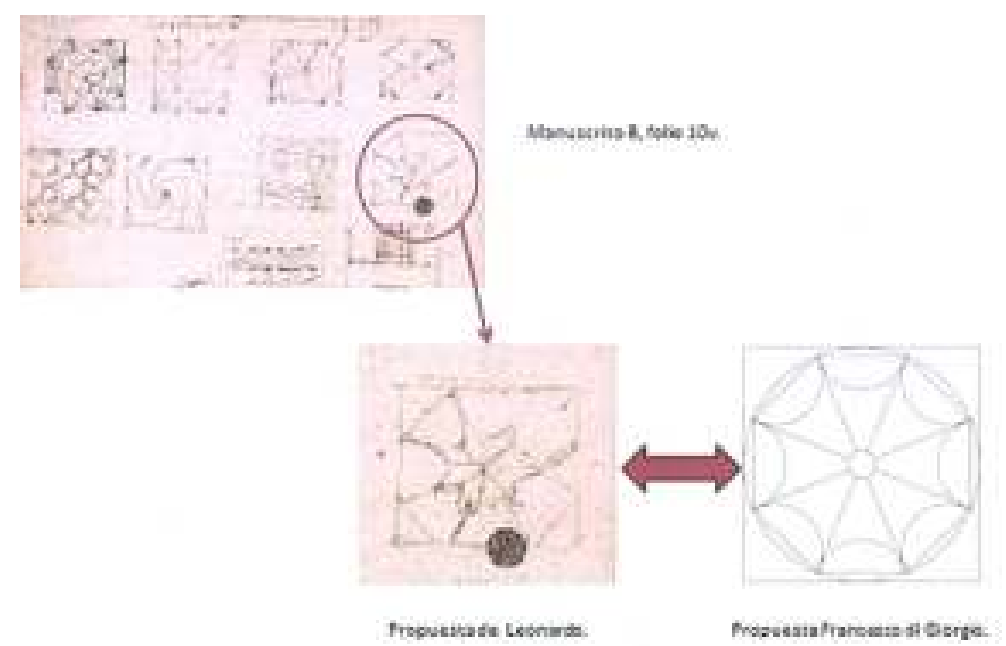




\section{Discussion}

The Renaissance brought about a change in architecture and their architects. These became considered from anonymous to have a personal style in their work. This unknown authorship in the architecture field, i.e. cathedrals is called as "the cathedral secret" (Arévalo, 2000: 64) by Martinez de Aranda, after the silence when constructing these buildings. This idea is also shared by Lotz, when he says: "We have never found a drawing by an Italian architect truly dated before 1460. The first drawings are dated after the last quarter of the XV century" (Lotz, 1985: 1-8).

The author Arevalo says that not finding any drawing does not imply their non existence. Before the Renaissance the graphic representations took place on things such as plaster, wooden pieces, or on the floor itself; they were more economic compared to the papyrus sheet (Arévalo, 2000).

All these secrets were due to the work method used during The Middle Ages and still in the Renaissance that is, the guild system. It consisted of a model of economic association that joined people working in the same field and following the same regulations. They appeared in The Middle Ages and continued until the factory birth when the beginning of the Industrial Revolution. Their objectives were those of guarantee the work and their economic conditions, regulation of the learning system and the knowledge of the future workers (Moreno, 2001). The painter Cenino tells us about an artisan-artist learning process:

First of all you shall spend a minimum of a year practicing drawing on a little slate pencil; after you shall learn all the branches composing our art with the master in the workshop. After that you must learn to prepare paints, to cook the glue, to ground plaster and the method to primer; you must learn how to emboss, to gild, to stipple for six long years. Once finished you will pass the painting tests, to put up decorations, to make curtains, to master the wall paint for six more years (AA.VV. 2013: 125).

The guilds were structured in three different levels: master-official-learner. As Luigi Vagneti says in his book L'architect nellastoria de occidente, these guilds were called by different names depending on the place they worked, in Venetia they were matricole, in Padua fragile, in Lombardia consolati, in Rome universitá. In the other European contries they were maitrises in France, in Spain guilds (Vagnetti, 1973).

The architecture was not considered as an isolated work so that it did not have a specific learning system. Generally speaking the Renaissance architect had had his culture through a different art: the sculpture the painting or the goldsmithing. In this way if the learner proved his abilities in the studied guild-art and after he acquired knowledge in arithmetic, geometry, and theory of the proportions, the artist himself might become an architect (AA.VV., 2013).

Considering the classification of the middle ages arts, they could be liberal arts or mechanical arts. The former were studied in the universities and the latter with the guilds. The sculpture and painting were considered mechanical arts, so they only could be learnt with masters (AA.VV., 2013).

The first historical reference that we have proofs related to the qualification of an architect was written down by Vitruvio in his master piece De Architecture, in the year 80 B.C. the compiling work consists of topics related with architecture, organized in ten books and dedicated to the Emperor August. For Vitruvio:

The architecture is a science rising from many others, and adorned with varied learning; helped by the idea you have from those works that are the result from different arts. Practice and theory are both his parents. Practice is the frequent and continued contemplation of the way a work takes place, or the mere execution of the hands to handle the material the best way and most suitable final piece. The theory is the result of that reason that demons and explains that the forged material was intended to be that way as intended from the beginning. Since the mere practical architect is not capable to give reasons enough for 
the forms he uses; the theoretical architect also fails when focusing the shadows not the inner substance That is why the one being both practical and theoretical built double. He could not only test the convenience of his design, but to be able to execute it as well [...] And I will say that he will be awitty and reasonable man in his learning. Neither the ability without studying, nor learning without inner material will do a good master. And he must be clever and learned, liberal, good drawer, he will knows forward planning, able to count. He knows history and antiquity, he has learned natural philosophy and astrology and some medicine. He listens to music and has paid the building laws in the different towns [...] First of all he must be a learner and know what happened before and that knowledge should be consolidated and well learned, [...] The geometry helps much to this art of building. Since his hand already masters the using of the compass, he will be able to draw to get molds and to draw the ground floor shapes (Vitruvio, 1999: 10).

In the Renaissance, the architect Leon Battista Alberti, who studied at the Padua University, stablished in the prologue of his book 1 De re aedificatoria:

The architect is that one who having a method and a procedure, both concrete and admired, has studied the way to project in practice and in theory any work that from the movement of the weights and the union of the bodies, is suitable to the necessities of the human beings in a beautifully way (Battista, 1991: 57).

In this definition he does not mention a university formation, Battista himself got it, but to the qualities and knowledge a person should have when working as an architect; It is not important whether they are acquired from masters or at the university.

Francesco di Giorgio in his book Trattato di archittectura civile e militare, Quarto Trattato denominate il Templi:

Ma se l'architettore non ha prespicase e sigulare ingegno e invenzione, none aspetti mai perfettamente tale arte esercitar potere, imperò chel' architettura ̀̀ solo una sittile immaginzazione concetta in nellamente la quale in nell'oprasi manifesta. Anco è da notareched'ogni e ciascunacosa non sipuò la ragione assegnare, perchè lo ingegno consiste più unne llamente e in nello intelletto dell 'architettoreche in iscrittura o disegno, e molte cose accade in fatto le qualil' architetto overo opratore maipensò. E imperò bisogna che esso architettore sia pratico e sciente, memorioso e che abbiletto e vedutomolte cose e alla cosa che segueessarepreparato. E non siccomemoltiarroganti e presunuosi i qualinellierrorifondatisono e per forzadellalingnia loro el falso dimostrando el mondo hannocorrotto. E per volere in parte le ragionid'essaarchitetturasiccomeseguiràdiscriverò. In prima è da saperedue cose essare grandemente necessarie: frabica e eciocinazio. La frabica è circa all'uso e pensierodell'opare. Raciocinazio è demostrare le cose, innanzi che fabbricatesieno, con proporzionataragione. E siccomedice Vetrivio all parchitettoingegno e dottrina a lui bisogna, perchè lo ingegnosenzadottrina o la dottrinasenzaigegnol'arteficeperfettofar non può (Giorgio, 1967: 36) (Appendix A-14).

Vincenzo Scamozzi, in his book L'idea dell architettura universale, says:

É molto conueneuolcofa, chel' Architetto fappia almeno i principi, è termini niuerfali di tutte le Arti, e magifteri, cheoccorrono j cosialla prcparatione delle materie, come per coftruirc, ornareefi edifici in modo tale però, che non le fappia comearte fice, ma come Filosofo (Scamozzi, 1615: 24).

Girolamo Maggi also wrote in his book Della fortification delle citta, the characteristics an architect should have: 
Bisogna, che il l etteratonell Architettura había disegno, sia perito dell arte del misurare, intenda la prospettiva, sapia Arismettica, conoscamolte Historie, posseda la Filosofia, intenda la Musica, la Medicina, le Leggi. . . (Makri, 2013: 103) (Appendix 15).

It is interesting to know that none author refers to the necessity of official studying to be an architect. Almost they all refer to the qualities and knowledge an architect must have related to the theme. During the Renaissance those requirements were not necessary; that is why they quite often were artisans belonging to specific guilds. They had their knowledge from their masters or reading books and codices.

\section{Materials and Methods}

Research is the activity developed by people to find solutions to problems through the use of scientific processes. These processes are what will allow us to establish the methodology to follow in the path of research. The term methodology has an important number of definitions, but in this case and based on the dictionary of the Royal Spanish Academy, it is understood as: "A set of methods that are followed in a scientific investigation or in a doctrinal exposition". In the investigation that has been carried out for the elaboration of the present investigation, the processes denominated "inductive" and "deductive" have been used. Both must be complementary during the development of the investigation and have allowed to obtain the conclusions that are exposed in the corresponding section.

The elaboration of this publication has required the careful study of the copies of Leonardo da Vinci's manuscripts, located in the Ambrosian Library of Vinci, (Italy) and Castle Clos Luce in Amboise (France).

\section{Conclusions}

Leonardo da Vinci is considered in the history of the humanity like an exceptional genius, emphasized in subjects like painting, optics, mechanics, botany, medicine and as inventor. Their proposals in these areas have been considered later as exceptional inventions. It is now difficult to find references of its facet within the architecture. During the development exposed in the article can be verified that this field was treated by Leonardo with great depth and discipline. However, it has not historically supposed to be designated as an architect. Surely the main reason for this situation is the lack of actual evidence to materialize their architectural studies. However, it is necessary to indicate that at present only $40 \%$ of the 15,000 pages that Leonardo has been able to write throughout his life are available. It is therefore difficult to guarantee the absence of real evidence within this field.

Leonardo did not do official studies such as the cases of Leon Battista Alberti or Vincenzo Scamozzi, but like Francesco di Giorgio, Baldassarre Peruzzi and others, he learned the knowledge and the trade through the system of learning of the time: the guild system. Knowledge, theories, proposals and projects that he left reflected in his Codices and Manuscripts but that for various circumstances there was no evidence of its execution. What has arrived until our days are the innumerable written references of other authors or historical personages, in which Leonardo is denominated with the qualifier of architect. Thus, and to cite some examples, it is the case of Francisco I who treated him as "the first painter, architect and mechanic of the court" (Navoni, 2012: 14), Anonymous Magliabechiano, who describes it in his manuscript as "architetto e pittore" (Pedretti, 1988: 207). Or the Italian writer, humanist and historian, Benedetto Varchi, who wrote in Michelangelo's funeral prayer of 1564 "Haveva oltra l'architettura, oltra la Scultura, per his principal art, and professione di o sollazzo e intertenimento la Pittura" (Appendix 16). 
Leonardo, without being considered as a professional architect, had knowledge related to design, structural calculation, building materials and construction systems, which allowed him to propose a brilliant performance in the Duomo of Milan. This knowledge occupies only 22 pages of the 6,000 that are of public access, which is $0.36 \%$ of its artistic production. It should not be forgotten that this intervention is considered one of the two most important works of the Renaissance together with the Dome of the Fiore in Florence.It is not necessary to emphasize the practical character of Leonardo's works and the wisdom of which he used throughout his life. Two virtues which are included in the development of his works and in the fact of having belonged and participated in the meetings of sages and thinkers of the courts of Lorenzo the Magnificent and Ludovico Sforza.

Conflicts of Interest: Declare conflicts of interest or state "The authors declare no conflict of interest."

\section{Appendix A}

1- Traduction autor: The obstinate rigor is the only tool that allowed him to identify the correct form of the experimental investigation in architecture.

2- Francesco di Giorgio Martini moved to Milan in 1490 to enter the contest from the Venerable Factory of the Duomo of Milan to build his dome. He met there Leonardo and began to work together.

3- Donato Bramante was born in 1443 in Monte Asdrualdo, near Urbino. He was a painter and architect, he moved to Milan around 1480, there he built several churches following the ancient form and meaning regulations. He met Leonardo working in the restoration of Santa Maria delle Grazie. Donato Bramante arrived in Milan between 1480 and 1490 and soon he became the official architect of Ludovico Sforza. His first works were to restore and to build the churches in Milan. Leonardo and Bramante became friends and shared some projects such as the Duomo dome in Milan, the Duomo of Pavia, or Santa Maria de la Grazie. Bramante is known as the first to introduce the Renaissance in Milan. That is why it is important the relation and the work shared with Leonardo and his influence.

4- Luca Pacioli Franciscan frier, with 19 years old taught arithmetic, geometry and accounting. Leonardo met him in 1498 in Milan and tried to learn from him everything related to geometry. They had a close relation and after it Pacioli published a treaty called Divine Proportion in 1498 with 60 polyhedron illustrations made of water colors by Leonardo

5- Author translation: Leonardo learnt part of his architecture knowledge after a detailed study of the military and civil treaty by Francesco di Giorgio.

6- The manuscript B is included in the collection Manuscripts of France. Its name is due to their robbery by Napoleon Bonaparte in 1795 and then taken to the institute of France in Paris. They are composed by 12 identified codices with the letters from A to M. The manuscript B was written by Leonardo when he was 30 and then presented to Ludovico Sforza as a military engineer. It is written in 100 pages with dimensions of $23 \mathrm{cmt} \times 16 \mathrm{cmt}$. It was begun in the page 100 and written as the rest from right to left.

7- Author translation: The main reason is that the Duomo dome looked like falling down, where it has been desmounted and it is being investigated how to recover it.

8- We should not be surprised by the situation untidied apparently. As Pedretti (2013) says: "Leonardo was a bit absent minded and used to study some subject at the same time [...] And all this process was reflected in the Codices where he was currently working" (Pedretti, 2013:33).

9- It is an imposed name by the autor Lotz who considers it as "one of the first examples of this method drawn systematically".

10- Related to the representation method of buildings described by the architects Antonio Averlino, Filipo Bruneleschi or Leon Battista Alberti, they stablish as a final base of his process, making a model reflecting in detail the element they want to build.

11- Author translation : Repairs on the model. 
12- The building Works began in 1487 ordered by Ascanio Sforza brother of Ludovico Sforza. The first projects were in 1488 and a year later Bramante was asked to explain the work he was carrying out.

13- Tafuri is the only one who uses the Word "rifutati" (1972: note 3). Author translation: rejected, to refer to Leonardo's propose. For him, Leonardo did not abandon but his project was rejected.

14- Translation from Vera, A., "The Renaissance military architecture through the writers from the XV and XVI, Valencia, doctoral thesis in Valencia Technical College, 2010. 'The architect who is no witty, sharp and inventive will not be able to work in this art, since the architecture is only a subtle thought in your mind and taking place in the work. That is why from everything the reason cannot be shown, the ingenuity rises more from the mind and in the architect's mind than in his writing or the design, many things really happen and were thought neither by the worker nor the architect. So that he architect should be practical and wise, have memory, have read and seen many things to be ready for anything. First of all he must know two very important things: work and reasoning. The work refers to the use and thought of the action. And as Vitruvio says the architect needs ingeniu tying doctrine since the ingenuity without knowledge or this without ingenuity cannot make the perfect work".

15- Author translation: It is required that the architect can draw, experience in measurement, in perspective, he can do arithmetic, history, philosophy, he can listen to music, medicine and the laws.

16- Author translation: Leonardo had besides the architecture, the sculpture, nevertheless his main art, profession and hobby was painting.

\section{References}

Anna Suh. 2006. Leonardo da Vinci, notebooks. Barcelona, Edition Parragón, pp. 199.

Arévalo, Federico. 2000. The representation of the city in the Renaissance: urban and territorial uprising.

Doctoral Thesis Higher Technical School of Architecture. University of Seville, Seville, Spain.

AA.VV. 2013. Leonardo da Vinci. Madrid: Editions Susaeta, pp. 100-125.

Battista, León. 1991. De re aedificatoria (Traduction of Javier Fresnillo Núñez). Madrid, Editions Akal, pp. 57-60.

Bruschi, Arnaldo. 1987. Bramante. Bilbao, Xarait edition, pp. 119-130.

Chavez, Pedro. 2003. Scientific Proof: methods of investigation. Mexico, Cultural Publications, pp. 80.

Da Vinci, Leonardo. S.F. Facsimile Atlantic Codex. Vinci Ambrosiana library, Vinci, Italy.

Da Vinci, Leonardo. S.F. Facsimile Manuscript B. Vinci Ambrosiana library, Vinci, Italy.

Da Vinci, Leonardo. S.F. Facsimile Trivulzian Codex. Vinci Ambrosiana library, Vinci, Italy.

Giorgio, Francesco. 1967. Tratatti di architettura ingegneria e arte militare. Milán, Maltese, pp. 36-37.

Lotz, Wolfgang. 1985. The architecture of the Renaissance in Italy: studies. Milán: Editorial Hermann Blume, pp. 1-8.

Moreno, Bibiana. 2001. Artists and artisans of the Granada Baroque. Documentation and historical study of the guilds. Granada: Editorial University of Granada, Granada, Spain.

Mrakic, Andrea. 2013. The development of military constructive knowledge. From Vitruvius to the 17th century. Doctoral Thesis Politecnic. University of Valencia, Valencia, Spain.

Navoni, Marco 2012. Leonardo da Vinci and the secrets of the Atlantic Codex. Milán, Edition Hernann Blume, pp. 14.

Pedretti, Carlo. 1988. Leonardo Architetto. Milán, Editions Electa, pp. 34-35, 137, 206.

Pedretti, Carlo. 2013. Leonardo Architetto. Madrid: Editions Susaeta, pp. 108.

Rowe, Colin. 2013. The architecture of the sixteenth century in Italy. Barcelona, Edition Reverté, pp. 32-33.

Scamozzi, Vincenzo. 1615. L urbanística dell architettura universal. Library Hospital Real, University of Granada, Granada, Book I, Chapter VIII: 24.

Tafuri, M. 1972. L'architettura dell' umanessimo. Bari, Edition Laterza, pp. 25 and note 3.

Taglialagamba, Sara. 2010. Leonardo\&L Arquitectura, Poggio a Caiano, CB Edition, pp. 20-25

Vagnetti, Luigi. 1973. L'architectonellastoria di occidente. Florencia, Editorial Teorema.

Vasari, Giorgio. 2005. Vite de' più eccellenti architetti, pittori, et scultori italiani, da Cimabue insino a' tempi nostril (Trad. Spanish of Ana Ávila). Madrid, Edition Cátedra, pp. 175). 
13 of 13

469 Vitruvio, Marco. 1999. X Books of architecture. Cáceres, Cicón editions, pp. 10-15. 